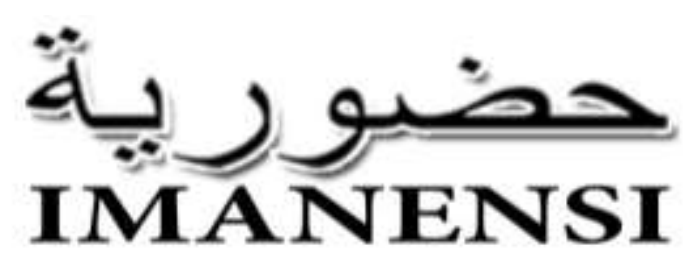

Jurnal Ekonomi, Manajemen, dan Akuntansi Islam

Vol 5, No 1, Maret 2020, Hlmn. 1-16

\title{
From jahiliyyah to Islamic worldview: in search of an Islamic economic philosophy ${ }^{1}$
}

\author{
Mohd Shukri Hanapi a,1,* \\ Centre for Islamic Development Management Studies (ISDEV), School of \\ Social Sciences, Universiti Sains Malaysia, 11800 Gelugor, Penang, \\ Malaysia \\ 1 hshukeri@gmail.com / hshukri@usm.my * \\ * correspondence author

\begin{abstract}
This paper attempts to seek answers, Firstly, it intends to identify Jahiliyyah practices that are allegedly accepted and practiced in Islam. Secondly, to analyze the worldview of these Jahiliyyah-origin practices within an Islamic worldview construct. The analysis was based on selected practices of the Jahiliyyah that were adopted by Rasulullah SAW. This historiography study concludes that the similarities of these practices, if any, eventhough are similar to those practiced by the Jahiliyyah, were only restricted to its names and terms, while the structure and roots were revamped by Rasulullah SAW. The divine revelations received by Rasulullah SAW are proof that Islam is absolutely free from Jahiliyyah practices. The arguments used by those who advocate the use of conventional ideas to solve problems related to Islam are therefore, incorrect.
\end{abstract}

Kerywords: Jahiliyyah; Islamic Worldview; Islamic Philosophical Construct; Historiography.

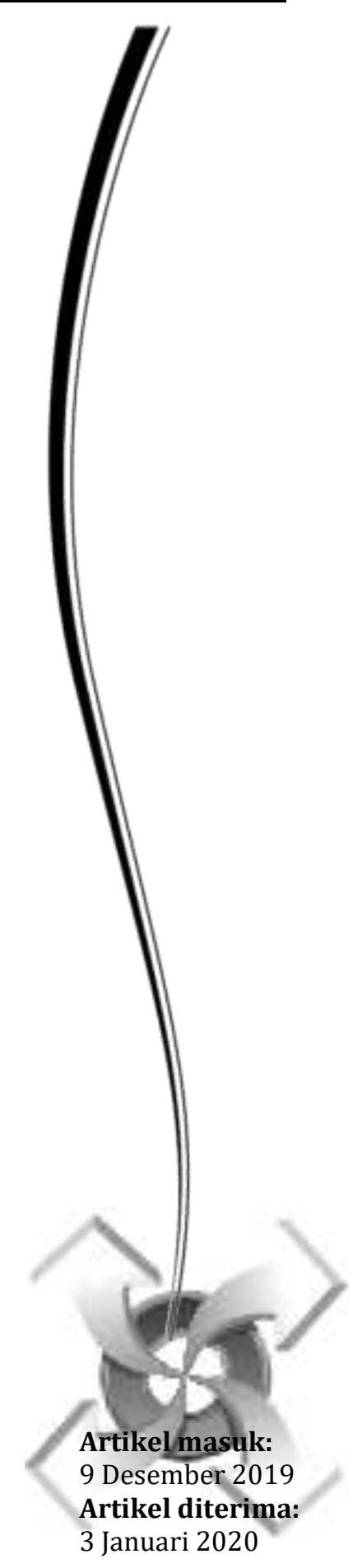

1 The article has been presented in the International Conference Religious and Culcural Pradox in Social, Economic and Business Sciences (INCRECS), organized by Yayasan Rumah Panaleh and ALJEBI, at Surabaya, East Java, Indonesia, on 16-17 October 2019.

This is an open access article under the CC-BY-SA license. 


\section{INTRODUCTION}

In efforts to solve challenges and issues related to Islam, especially the Islamic economic aspect, it is observed that conventional development theories are mostly used. In actual fact, there is a group of scholars using these types of conventional development theories who are of the opinion that these theories can be applied or used to manage issues and problems related to Islam as long as these theories are not contrary to Islamic principles. In reinforcing their views, they reasoned that several Jahilliyyah practices were accepted in Islam. Apparently they equated this process by using theories and methods from conventional development when solving issues and problems related to Islam.

This pattern of thinking has existed for quite some time, especially in Islamic economic. It is known as the accommodative-modification school of thought with eclectism-methodological characteristics. This accommodativemodification approach refers to a method of readily accepting and improving non-Islamic economic thinking to turn it into Islamic economics. The eclectism-methodological approach on the other hand refers to the flexible, selection--based approach that is deemed appropriate compared to various other approaches and thereafter used it collectively in Islamic economic. These accommodative-modification and the eclectism-methodological approaches provide the justification that contributions from other disciplines, such as neo-classical theories, are acceptable (Salleh, 2011).

The logical argument that is usually referred to by scholars from the accommodative-modification and eclectism-methodological schools of thought is in accordance to those presented by Chapra (2001) and Ahmed (2002). According to Chapra (2001:30), the Islamic economy can use conventional economics theories as long as these theories are not contrary to the Islamic worldview's logical structure. This is consistent with the views of Ahmed (2002). He believed that Islamic economy is a unique combination of syar'iah principles and conventional economy. As long as the concepts and economic principles do not contradict Islamic principles, it can be adapted into Islamic economy (Salleh, 2011).

According to Salleh (2011), the existence of accommodative-modification and eclectism-methodological approaches is due to its advocators' incoherence about the difference between the philosophical and operational stages in Islamic economic itself. The philosophical stage in Islamic economy comprises components that build the Islamic economy's framework that contains the Islamic worldview, philosophical basis and definitions of the concept of Islamic economy. Furthermore, the operational stage in Islamic economy comprises values, theories, tools and methods for implementing the Islamic economy. It represents the components that allow for the realisation of an Islamic economic. Between these two stages, the core is the philosophical stage, whereas the components in the operational stage can be shaped in accordance with its philosophical basis. Thus, if only the components in the operational levels are chosen, accommodated and thereafter modified in accordance to Islam whereas its framework at the philosophical stage is based on the conventional economy framework, then the components at the operational stage will not be absolutely and truly Islamic.

It is in relation to the accommodative-modification approach with eclectism-methodological characteristics issues that this working paper is written. It has two main purposes. One is to identify several Jahiliyyah practices that are accepted by Islam and the other is to analyse the worldview on the Jahilliyyah-Islamic practices as well as its concepts. The analysis is 
based on several selected Jahilliyyah practices that have been adopted by Islam. Findings from this analysis will then determine whether the Islamic approach used by Rasulullah SAW is similar to the accommodativemodification and eclectism-methodological approaches or vice versa.

These discussions are arranged into five sections. The first section examines the views of advocators of the accommodative-modification school of thought with eclectism-methodological characteristics. The second section examines the background and worldview of the Arab Jahilliyyah society. The third section examines the Arab Jahilliyyah societal practices that are accepted in Islam. The fourth section analyses the worldview of the Jahilliyyah-Islamic practices and the fifth section concludes this paper.

\section{RESULT AND DISCUSSION}

\section{A. Advocates Of The Accommondative-Modofication School Of Thought} With Eclectism-Methodological Characteristics In Islamic Economic

Generally, there are two schools of thought that are dominant in Islamic economics. First is the accommondative-modofication approach with eclectism-methodological characteristics and the second is the revamp of the grassroots approach (based on the Islamic worldview) ${ }^{2}$. Among these two approaches, the most widely used as a mould for Islamic economics is the accommondative-modofication approach with eclectic-methodological characteristics. The accommondative-modofication approach with eclecticmethodological characteristics was pioneered by mainstream Islamic economists. According to Muhammad Syukri Salleh (2011), among these mainstream Islamic economists were Manan (1984), Siddiqi (1989), Khaf (1987), Jomo (1992), and Abbas (2008).

As for Mannan (1984), Siddiqi (1989) and Khaf (1987), their line of thought was the core element for scholars who had formed the accommondativemodofication approach with eclectic-methodological characteristics (Salleh, 2011). Manan (1984) had used the eclectic approach by adopting Western economic thinking, whereas Siddiqi (1989: 1-11) and Khaf (1987) had combined neo-classical economic theory with fiqh leading to an approach called fiqh-based neo-classical theory. Similarly, Abbas (2008) believed that "Islamic socialism economy", based on "religioussosialism" by Muhammad Hatta (Bung Hatta), can be incorporated into Islamic development. This case is similar to the line of thinking endorsed by Jomo (1992), which is an alternative line of thinking. All these Islamic economists had tried to use the

\footnotetext{
2 Among the advocates of this line of thinking are Abdul-Hamid Ahmad Abu-Sulayman (1973) and Ziaudin Sardar (1988, 1999 \& 2011). According to Abdul-Hamid Ahmad Abu-Sulayman (1973), when forming something (economic development) based on Islam, not only the philosophy must be revamped but the theories should also go through the same process towards Islam. This is because Islam will always be relevant, previously, presently and in the future. According to Surtahman Kastin Hassan and Sanep Ahmad (2010), by retracing Islamicbased development through the cultivation of traditional Islamic epistemology, such as using the total revamp of grassroots method on previous knowledge on development (such as works by Abu Yusuf, Ibn Khaldun, Ibn Taymiyyah and al-Ghazaliy that are far more advanced compared to the thinking of Adam Smith and Karl-Marx) by redesigning the facts so that it is suitable with contemporary conditions and situations. Therefore, the analysis of Islamic-based development (economics) requires vast knowledge and in-depth understanding when discussing traditional Islamic-based development knowledge, while its implementation is far more complex and needs scientific proof (Zakaria Bahari, 2014). Although this retracing goes back a long way, this is the most noble and best way to form Islamic-based development (Surtahman Kastin Hassan \& Sanep Ahmad, 2010:64).
} 
combination between Islamic economy and the other lisms to produce a separate line of thinking as an Islamic economic mould (Salleh, 2011).

In order to propagate the accommondative-modofication approach with eclectism-methodological characteristics, numerous logical arguments have been highlighted by its advocates. Among these advocates are Chapra (2001), Ahmed (2002), Isa (2009) and Dusuki (2013). According to Chapra (2001:38), conventional economic theories can be used to form Islamic economics if these theories do not contradict Islamic worldview's logical structure. In relation to this, Chapra (2001) was of the view that:

"Islamic economics can also adopt conventional economics theories that have become a part of conventional wisdom, if these theories are not in conflict with the logical structure of the Islamic worldview".

According to Chapra (2001), use of the accommondative-modofication approach with eclectism-methodological characteristics can be used as an Islamic economic mould. This was substantiated by the argument put forth by the wisdom of conventional economy when developing a country's economy. The question is whether pure Islamic economic theory has more compehensive benefits compared to conventional economic theory. Why is it necessary to combine Islamic economic theory and conventional economic theory to form and develop an economy?

According to Abdel Ahmed (2002), Islamic economy is a unique combination of syariah principles and conventional economy. As long as conventional concepts and principles do not contradict Islamic principles, it can be applied in Islamic economy. In relation to this, Ahmed (2002) mentioned that:

“...we need to explore the relationship between Islamic economics and secular economics and identify the elements that can be adopted from the latter ...Islamic economics and the interlinkages between it and Islamic legal prinsiples and creed values. Once this in comprehended, a relationship with secular economics can be visualized and established on solid scientific basis."

According to Ahmed (2002), the accommondative-modofication approach with eclectism-methodological characteristics is the basis for forming the mould for Islamic economics. Combining conventional economy and Islamic syariah principles is how the Islamic economic mould is built, which is stronger and scientific in nature. The question is whether only this combination can yield an Islamic economy that is scientific in nature. Can an Islamic economy that is scientific in nature be achieved by just using pure Islamic worldview (tasawur) and syariah principles?

In a similar vein, Isa (2009) stated that Islamic scholars can use conventional economy as an initial step and make reviews to select elements that are permitted in Islam, change inappropriate elements and reject what is clearly prohibited. Isa (2009) mentioned that:

"...this approach is much more easier and practical considering its stability from the theoritical and practical aspects of conventional economy. Islamic scholars can use conventional economy as a starting point and make reviews to select what is ainappropriate and reject what is clearly prohibited."

Regarding the statement by Isa (2009), the accommondative-modofication approach with eclectism-methodological characteristics is used to form Islamic economic theories and practices by reviewing conventional economic theories 
and practices. Thus, arises a question, is the accommondative-modofication approach with eclectism-methodological characteristics permitted in Islam? Does Islam have its own economic practices that allow a review of conventional economy to form Islamic economy?

The views of Chapra (2001), Ahmed (2002) and Isa (2009) are supported by the argument that Islam accepts some of the practices of the Jahilliyyah and practiced in Islam. Hence, in relation to the accommondative-modofication approach with eclectism-methodological characteristics that act as an Islamic economic mould, it is permitted. In relation to this, Dusuki (2013) was of the view that:

"...the accommodative attitude of Islamic scholars and academicians in accepting the resovior of foreign knowledge is actually not something new or something that is premeditated. This a continuation od the culture of principles that were practiced by the Prophet SAW Himself and the Prophet's SAW effort to carry out reforms and transformations on the Arab Jahiliah community until the formation of a remarkable Islamic civilization centred in Madinah. The coming of the Prophet SAW had actually seen the openness towards traditional practices that did not contradict the demands of divine revelation. The taghyir (changes) dan takrir (acknowledge) principles are two approches that were used to develop the early generation of Islam ..."

Dusuki (2013) suggested that the acceptence by the Prophet SAW of several practices of the Jahilliyyah could be an argument for permitting the accommondative-modofication approach with eclectism-methodological characteristics to form the Islamic economic mould. The question is whether the concept of Jahilliyyah practices that are adopted and practiced in Islam, without any amendments, are actually similar to the concept of Islamic practices. Or, is it only similar in terms of practices but its concept has been revamped and differs with that of Islamic practices?

\section{B. The Jahilliyyah Meaning And Its Period}

The term Jahilliyyah originates from the Arabic word jahala meaning ignorance or not having knowledge. In the Quran (al-Maidah,5:50), the term Jahilliyyah refers to a pre-Islamic society living in the Arabian Peninsula. They were a society plagued with ignorance, had rejected Allah SWT's guidance, had no moral values, were not civilized, were illeterate and disobedient towards the laws of Allah SWT (Syakir, 1991:10; Bennabi, 2009:65).

The Arab Jahilliyyah society lived in the Arabian Peninsula during the period after the destruction of the Ma'arib Damp in Saba' around the year 300 AD. The duration of the Jahilliyyah period lasted about 310 years beginning from $300 \mathrm{AD}$ until $610 \mathrm{AD}$, as shown in Table 1. The Arab society that lived during this period were known as Arab Jahilliyyah as they did not follow the teachings of earlier Prophets and Messengers such as Prophet Sulaiman a.h., Prophet Ibrahim a.h, Prophet Ismail a.h., Prophet Musa a.h., Prophet Isa a.h. and others (Ismail, 2003:85).

The Jahilliyyah period is regarded as the dark period. At that time the Arab Jahilliyyah did not worship Allah SWT, the Almighty. In fact, most of them practiced idolatary and believed in animism. The Arab Jahilliyyah society lived a chaotic life as there were no Prophets or Messengers or holy books that could be used as a guide in their lives at that time. For example, good manners were almost non-existent as they were cruel, proud and stubborn (Syakir, 1991:10). With the arrival of Islam in the year $610 \mathrm{AD}$, the Arab 
Jahilliyyah society started to change. All aspects of their lives were shaped by the Islamic tasawwur (worldview), which comprised aspects of aqidah (faith), ibadah (worship) and akhlaq (manners).

Table 1: Duration of the Jahilliyyah Period

\begin{tabular}{ll}
\hline DATE & EVENT \\
\hline $300 \mathrm{AD}$ & Destruction of the Ma'arib Damp \\
$570 \mathrm{AD}$ & The Birth of Nabi Muhammad SAW \\
$610 \mathrm{AD}$ & $\begin{array}{l}\text { Beginning of Revealation to Prophet } \\
\text { Muhammad SAW. It is from here } \\
\text { that the Islamic period begins }\end{array}$ \\
\hline
\end{tabular}

\section{Worldview Of The Arab Jahilliyyah Society}

As mentioned above, the Arab Jahilliyyah society did not devote itself to Allah SWT, either in faith, worship or mannerism (Bennabi, 2009:60-61). In other words, their life was not based on tauhid (monotheism of Allah SWT). All their actions and practices were shaped solely by their minds and desires. With such a worldview, the Arab Jahilliyyah characteristics can be discerned according to several aspects. The first Aspect are Religion and Belief. In the Arab Jahilliyyah society, the rejection of any form of religion is attributed to several factors. First, they did not believe in the existence of Prophets and Messengers sent by Allah SWT.

Second, they changed the contents of the Taurat, which was delivered by Prophet Musa a.h. Third, there was no particular Prophet or Messenger or holy book that was sent specifically to them. Fourth, the spread of various religions within the Arabian Peninsula, in which the Persians propagated the Magi religion and the Romans spread Christianity; and fifth, there were some quarters who brought back religions from outside when they returned to Mecca. For example. 'Umar bin Luai who had gone to Syams and saw the Balqa' sect worshipping idols and thus, brought back the religion to Mecca (Ibn Kathir, 1989:174).

Consequently, Mecca became the centre for worshipping idolatory at that time. The religious sect on the other hand could be categorised into 5 sections, which are Wathani, Christianity, Magi, Jews and Hanif. Besides that a part of the Arab Jahilliyyah society practised animism such as belief in spirits, protectors, unseen powers, sun worshipping and tree worshipping. There were also beliefs that were regarded as nonsensical and imaginative such as fortune telling and observing the direction of flying birds. Hence, if the birds flew in the left direction then it is an omen that the journey was perilous and not safe and vice versa.

The second aspect is social. The Arab Jahilliyyah society was generally divided into two groups, namely the Bedouin and the Hadhari (civilized). The Bedouin lived in valleys and the upcountry, which is in the middle of the Arabian Peninsula. The Hadhari, on the other hand lived along the coast of the Arabian Peninsula. The differences in their settlement indirectly affected the different ways of life and achievements.

In addition, the Arab Jahilliyyah society was made up of various clans and tribes. Such a situation provided a number of negative effects. Among them was the emergence of 'asabiyyah (extreme feeling of closeness to one's clan and tribe), which usually resulted in the onset of war between these clans and 
tribes. A sense of 'asabiyyah was due to the set up that was based on clans and tribes. Each clan lived within its group and was bound to abide by the rules set by the clan. This further solidified the sense of clanship amongst clan members and they were prepared to seek revenge to safeguard the honour of the clan.

Besides that, the emergence of such social traits were closely related to the geographical circumstances where they lived, in which it was very hot and dry. For ensuring survival, each clan would need to overcome the problems collectively. The solidification towards the feeling of clanship had resulted in a Arab Jahilliyyah life that was chaotic and disordered. This usually became the source of animosity within the Arab Jahilliyyah society. War between differing clans would flare even due to trivial reasons. The al-Basus war between the Bakr and Rabi'ah clans exhibited a trait of the Arab Jahilliyyah society that took pleasure in fighting one another.

Furthermore women were not given the status they deserved whether within the family or the society. They regarded daughters upon reaching full age as plaguing them with social and economical problems. As such the Arab Jahilliyyah society were willing to bury their daughters alive such as was prevalent in the Tamin and Asad clans. They also wed without any limit.

Economy. The destruction of the Ma'arib Damp in Yemen had brought about a decline in the economy. Agricultural yield decreased drastically due to the poor irrigation system. The northern part consisted of the desert. As such trading activities were conducted in Mecca, Hirah and Ghassan. However trading was not profitable due to the bickering amongst clans. The Quraisy exploited trade and practised usury and suppression as well as pressured the Bedouin who lived in the desert. In retaliation the Bedouin robbed the Quraisy's caravans. Actually, the main economic activities of the Bedouin were rearing livestock, such as , cattle, camels, goats and sheep, in a nomadic fashion. They migrated constantly in search of greener pastures for their livestocks. Their economic activities symbolized a primitive life.

Politics. During the Jahilliyyah period none of the governments had a systematic and strong administration. Politics was in jeopardy due to colonization. The north was governed by the Roman and Persian empires, whereas the south was governed by the Habsyah (Euthopia) government. Mecca was badly affected by these conquests. The political climate of these colonized areas such as in Ghassan, Hirah and Yemen were unruly. The society, comprising various tribes, were regularly at war with one another. Although the country had its own administration nonetheless it could not be regarded as an advanced or civilized govenrment becuase it was under the rule of colonialists.

Based on the discussions above it could be seen that the worldview is the core or mould for all aspects of life. Hence, if the worldview is shaped by illicit means, then the whole aspect of life becomes chaotic and vice versa.

\section{The Jahilliyyah Practices Accepted In Islam}

The divine revelation delivered to Rasulullah SAW in the year 610 AD signified the beginning of the Islamic era. The coming of Islam had changed the Arab Jahilliyyah lifestyle. There were surmountable numbers of Arab Jahilliyyah practices that were eradicated by Islam, beginning from syirik rituals and daily practices to the smallest details consisting of the teasing methods of one another and other practices. However, not all the Arab Jahilliyyah practices were discarded. Conversely, a few of these Arab Jahilliyyah practices were accepted and used in Islam, as indicated in Table 2. 
Table 2: Jahilliyyah Practices Accepted in Islam

\begin{tabular}{cll}
\hline No. & Type of Practices & \multicolumn{1}{c}{$\begin{array}{c}\text { Practice Concept in } \\
\text { Jahilliyyah }\end{array}$} \\
\hline 1. $\quad \begin{array}{l}\text { Tawaf } \\
\text { (Circumambulation) }\end{array}$ & $\begin{array}{l}\text { The practice was executed in } \\
\text { nudity and by piercing the } \\
\text { bodywith spikes. According to } \\
\text { them the tawaf could not be } \\
\text { carried out when using } \\
\text { clothes that were worn when } \\
\text { making the sinful act (Ismail, } \\
\text { 2011) } \\
\text { 2. } \\
\text { Marriage }\end{array}$ \\
& $\begin{array}{l}\text { A man can marry as many } \\
\text { women as he pleased. In fact, } \\
\text { some of them had hundreds } \\
\text { of wives (Musa, 2009). }\end{array}$
\end{tabular}

Practice Concept in Islam

It is obligatory to perform the Tawaf while all the physical bodily aspects (aurat) are covered. (alA'raf, $7: 31$ )

A man is only allowed to marry up till four wives at any one time. However, it cannot be practiced according to one's whims and fancies, such as if the act oppresses women (alNisa', 4:3).

3. Zihar (a husband equating his wife with one of his mahram such as his mother or sisters)

Zihar is one way to divorce the wife. One way for a husband to solve his problem of no longer wanting to be with his wife is to utter the zihar by equating his wife to that of his mother (Nasir, 2010)

4. Qisas (Retaliation)

When a member of a clan is murdered then that clan can retaliate by killing as many members of the murderer's clan (Nuralhadi, t.t.)

Zihar is not one way of performing the talak (pronunciation of divorce), however, kaffarah (fine) is imposed (al-Mujadalah, $58: 1-4)$

Only the proven murderer faces the death penalty since Islam forbids killing without any lawful basis (al-An'am, 6:51)

5. Distribution of Estate

Women were oppressed. They were not in receipt of inheritance from their husband or family's estate. This negation of inheritance is because women were regarded as weak and of no use to each clan or tribe (Smith, 1990:117).

6. Sale and Purchase

Filled with usury and fraud especially when weighing goods (Sobrie, 2009)

Women have the rights of inheritance on her husband or family's estate (al-Nisa', 4:11, 12 \& 176).

Sales and Purchase are permitted but usury is forbidden. Furthermore, Islam provides the ethics for sale and purchase such as measurements need to be accurate and precise (alBaqarah, 2:275)

\section{Karam (Nobility)}

Nobility is earned through wealth, stature and having many children (Izutsu, 1964:36-38)
Nobility is earned through taqwa (piety) to Allah SWT (al-Hujurat, 49:13). 
8. War

9. Social Relations

10. Slavery

11. 'Aqilah (Compensation for Murder or Blood Money)

12. Tijarah (Sale and Purchase)
War as a result of pride and the 'asabiyyah spirit. In addition, it is regarded as a noble profession.

Separated life within each clan and tribe. Each individual is very proud of his clan and prejudicial against the other clan. This caused them to be partial to one tribe regardless whether they are in the right or wrong. This situation has led to animosity amongst tribes.

The master-slave relationship was full of oppression, humiliation and exploitation. As an example when a person failed to pay his debts or was a bankrupt then he can be made a slave. Slavery could also serve as a punishment for a criminal offense. It was also the case if a man from one tribe was captured by a dominant tribe, then the man together with his tribe could be subjected to slavery.

Should a murder occur, the murderer is required to compnesate (diyat) the family of the victim. The compensation is collected from members of the clan or tribe of the murderer.

Dipenuhi riba dan penipuan dalam sukatan dan timbangan (Sobrie, 2009)
Safeguards the sanctity of the religion, race and society from intrusion. A few guidelines which are obligatory are also provided. (al-Baqarah, 2:190; al-Baqarah, 2:193; al-Baqarah, 2:224)

The Muslim society in Medina was able to successfully build an Islamic society regardless of race and tribes. Loyalty to tribes no longer existed and replaced with the bond of brotherhood (al-Hujurat, 49:10). For example, Rasulullah SAW successfully tied the kinship of brotherhood among the Ansar with the Muhajirin.

The advent of Islam did not obliterate slavery but Islam provided guidelines on the laws regarding slavery since slaves are also humans whose intrinsic nature are the same with a free man. Allah SWT forbids the exploitation of slaves by their masters (alNur, 24:33)

The compensation is only paid by men of sound mind from the father's side ('asabah nasab) (Hanapi \& Latib, 2003:14-15).

Jual beli dihalalkan dan riba diharamkan. Selain itu, Islam menetapkan etika berjual beli seperti sukatan dan timbangan hendaklah tepat dan betul. Allah SWT berfirman yang bermaksud, "They say, "Trade is like usury," but Allah hath permitted trade and forbidden usury..." (alBaqarah, 2:275) 
13. Mudarabah (equlity, investment or deductions to be paid to the party undertaking the business). In other words, mudarabah means that the investor provides the modal to certain parties to invest and the profits or part of it to be divided among them according to the agreement between them during the akad. Whereas, losses from the investment would only be borne the investing party according to the conditions agreed upon by both parties.
During the Jahiliah era, trade that transversed territories and lasted for months were carried out extensively. Trade had involved the production or import of goods from one party and then sold or exported to other parties. In order to do this, the Arab Jahiliah community had introduced the mudarabah system. Mudarabah at that time was implemented by incorporating elements such as riba (usury), maysir (gambling), gharar (ambiguity), unfairness and cruelity (Chapra, 2000:39; Wiroso, S.E., 2005:34, i Hanapi, 2013)
Islam has legalised (syariat) the cooperative agreement of mudarabah to facilitate people because some people possess property but are unable to manage it. There are some who do not possess property but are capable of managing and developing it. Thus, syariat permits this cooperation so that both parties can reap the benefits. Sahib al-Mal (investor) provides benefits to the mudarib (manager) and the mudarib benefits the property by creating cooperation between the property and business practice (al-Thayar, 1993:122). Mudarabah in Islam has been agreed upon and practiced based on the sunnah (Hadis Riwayat Ibn Majah, no. 2289). Hence, Islam has restructured it by eradicating the practice of

mudarabah according to the Arab Jahilliyyah that contains elements of riba, maysir, gharar, unfairness and cruelty (Chapra, 2000:39). For that, Islam had introduced some crore principles and conditions for the mudarabah (Ibn Qudamah, 1991:172-177). 
14. Qard (debt-credit)

15. Rahn (Lease)
Existence of creditors who lend money to merchants for trading purposes. They receive payments together with interest and there are those who go into debt but when they repay their debt the payment is reduced. (Noordin. et al, 2005)
During the time of the Jahiliah, when the period of lease has expired and the lessee has not serviced the loan to the lessor, then the lessor will seal the items on lease without the permission of the lessee (al-Ghazali, 1996:520)
Islam suggest a distinct agreement regarding debt and when in debt, everything should be explained without increasing or reducing the debt (Kamaruzaman Noordin, Fadillah Mansor, Mohd. Rizal Muwazir @ Mukhazir, 2005). Allah SWT exhorted, meaning, "When you deal with each other in contracting a debt for a fixed time, then write it down. Let a scribe write it down between you with fairness; and the scribe should not flinch to write as Allah has taught him, so he should write exactly the way it is; and let him who owes the debt dictate" (alBaqarah, 2:282)

Allah SWT exhorted, meaning, "If you are on a journey and you do not find a scribe, then let there be a pledge taken (from the debtor) (this is sufficient)" (al-Baqarah, 2:283). Islam prohibits cruel methods, like the methods that existed during the Jahiliah era. Islam explains that items that are leased are a form of trust given to the murtahin and one cannot force the lessor to sell it except in situations where the lessee cannot aford to settle the debt when the maturity period expires. In this case the items can be sold to pay off the debt. If there is any surplus money after the items are sold then the remainder money becomes the right of the owner of the items. On the contrary, if the price of the items is inediquate for settling the debt, then the lessee must be responsible for the outstanding amount (debt) al-Ghazali, 1996:520) 
Figure 2 shows 15 practices of the Arab Jahilliyyah that are accepted in Islam, which are, tawaf (circumambulation), marriage, zihar, qisas, inheritance, buying and selling, karam concept, war, social relationship, slavery, 'aqilah, tijarah, mudarabah, qard and rahn. Actually, the identified 16 practices in this working paper represents only a part of the Arab Jahilliyyah society practises. It encompasses social and economic aspects. However, it is sufficient to prove the existence of major revamping of the structural basis of Jahilliyyah practices before they are accepted.

\section{E. Analysis Of The Jahilliyyah-Islam Practices Worldview}

Based on the Jahilliyyah-Islam practices depicted in Table 2 above, there are two glaring differences. According to Ibn Kathir (1989:177), the ArabJahilliyyah practices were based solely on al-syara' $i$ ' al-batilah (mind and appetitive), especially regarding the thinking of their leaders, such as 'Amru bin Luhai. At that time (for a period of 310 years) no Prophet or Messenger was sent to provide guidance, whereas the Arab Jahilliyyah practices that were adopted by Islam were restructured at its core and converted from the Jahilliyyah worldview to the Islamic worldview. Islamic worldview here refers to a comprehensive view as well as one portraying a true and correct picture of Islam that aims to explain the basic principles of Islam in a truthful and holistic manner such that it becomes the basis of life's views and ingrained within one's self (Din, 1992:3; Awang, 1997:6). All these basic elements, such as aqidah (faith), ibadah (worship) and akhlaq (manners) are contained in Allah SWT's divine revelation sent to Rasulullah SAW beginning in 610 AD.

It is evidently clear that Islam did not accept the Arab Jahilliyyah practices whole heartedly without changing the structural basis and its concepts. Although there are some similarities on the terminology of the practices, however the structural basis had been revamped and replaced with Islamic worldview. This revamping process had actually changed the concept and operations of the Arab Jahilliyyah practices. In other words, the concept and its operations are in accordance to the mould of Islamic worldview. Thus, these give rise to ibadah (worship) and akhlaq (manners) practices, which have aqidah (faith) as the core. If alluded to a tree, the core or root is aqidah, other roots are ibadah and its trunk is akhlaq. From here sprouts its branches and vines that are the concept and operations.

All these discussions on the worldview of Arab Jahilliyyah practices are summarized in Figure 1. This figure shows that Islam, which was propagated by Rasulullah SAW, had revamped the worldview of Arab Jahilliyyah practices and replaced it with an Islamic worldviewcomprising aqidah, ibadah and akhlaq. The revamp on the worldviewhas had a positive effect on the concept and operational aspects of Arab Jahilliyyah practices that are accepted by Islam.

It is evident that the 'total revamp at the grassroots' approach in Islam is not similar to the accommodative-modification and eclecticismmethodological approaches that only revamp the operational aspects. The Islamic educationists who supported the accommodative-modification and eclecticism-methodological approaches were confused about the differences at the philosophical and operational stages of Islamic education itself. The philosophical stage of Islamic education encompasses components that give rise to the Islamic education framework. In it contained the worldview, basic philosophy and definitions of the concepts of Islamic education. Islamic education operations on the other hand comprise values, theories, tools and pedagogy of Islamic education. It represents components that help in the 
realization of Islamic education. Between these two levels, the core is the philosophical stage or worldview, whereas the components in the operational stage are shaped according to its philosophical underpinning. If only the components in the operational level are selected, accommodated and thereafter, modified according to Islam whereas its framework at the philosophical stage is still based on the conventional education framework, then the components in the operational stage will not be absolutely and truly Islamic.

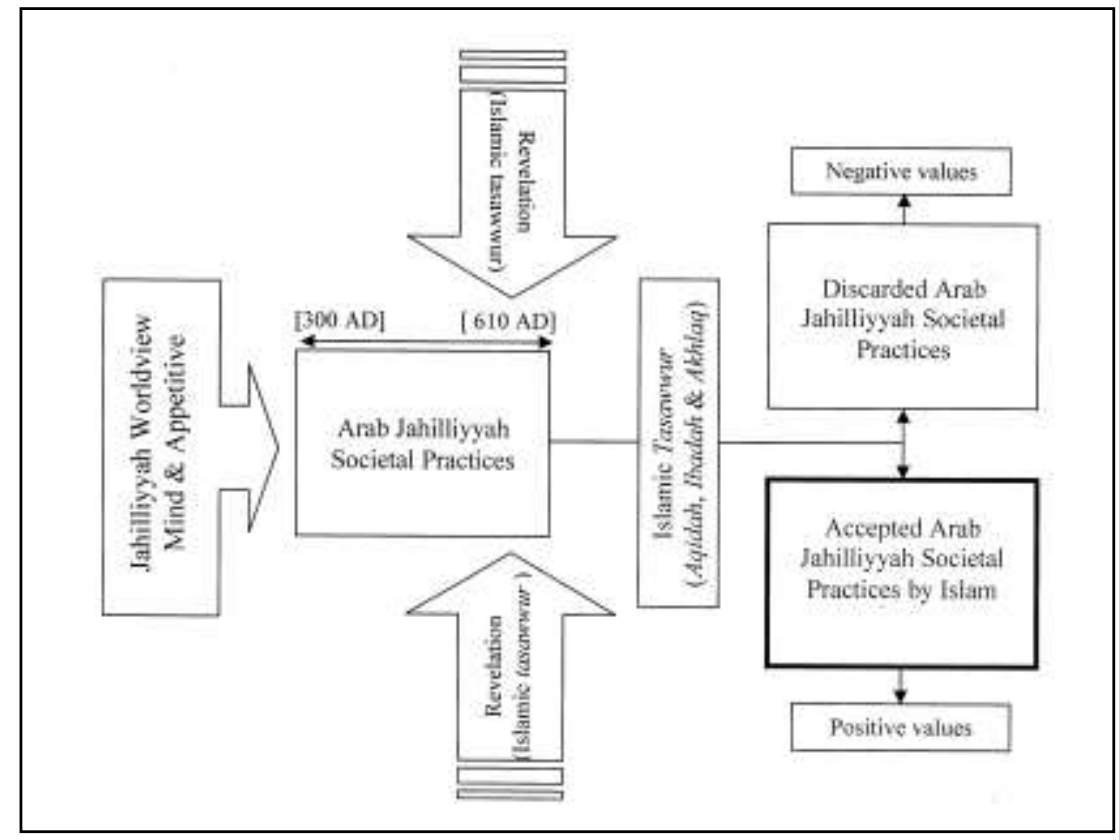

Figure 1: Revamping the Structural Basis of Arab Jahilliyyah-Islam Practices

\section{CONCLUSION}

The holistic discussion in this paper shows that Islam, as propagated by Rasulullah SAW, was not only able to revamp the concept and operational stage of Arab Jahilliyyah practices but it also revamped the philosophical or worldview aspects. Thus, it is evident that the logical reasoning usually used by the advocates of accommodative-modification and eclecticismmethodological approaches, as mentioned before, are not accurate. They are actually confused about the differences between the philosophical and operational stages. It is this "total" revamping approach brought by Islam that should be used in the realization of Islamic education today. The act of selecting what is deemed good from various sources and using it collectively in Islamic education is incorrect. A truly Islamic education system cannot be realized, built and implemented in so far its core, which is its philosophy or worldview, is still conventionally based.

\section{REFERENCE}

Abbas, A (2008). Bung Hatta \& Ekonomi Islam - Pergulatan Menangkap Makna Keadilan dan Kesejahteraan. Jakarta, Indonesia: LP3M STIE Ahmad Dahlan Jakarta \& Fakulti Hukum Universitas Muhammadiyah Jakarta. 
Abdullah, AR (2010). "Wacana Falsafah Sains Sejarah dan Pemikiran". Penang: Centre for Islamic Development Management Studies (ISDEV), Universiti Sains Malaysia.

Ahmad, FA (2010). Kaedah Pengurusan Institusi-Institusi Pembangunan berteraskan Islam di Malaysia. Shah Alam, Selangor: Pusat Penerbitan Universiti (UPENA), Universiti Teknologi MARA.

Ahmed, ARY (2002). "A Methodological Approach to Islamic Economics: Its Philosopy, Theoretical, Construction, and Applicability", in Habib Ahmed (ed.), Theoretical Foundations of Islamic Economics, Book of Readings No. 3. Jeddah, Saudi Arabia: Islamic Research and Training Institute, Islamic Development Bank.

Ahmed, H (2002). "Analytical Tools of Islamic Economic: A Modified Marginalist Approach", in Habib Ahmed (ed.), Theoritical Foundation of Islamic Economics. Books of Reading, No.3. Jeddah, Saudi Arabia: Islamic Research and Training Institute, Islamic Development Bank.

Al-Thayar, ABM. (1993). Al-Bunuk al-Islamiyyah Bayn 'an Nazariyyah wa Tatbiq. Riyad, Saudi Arabia: Mu'assasah al-Jurays.

Awang, A (1997). Tasawwur Rabbani Menurut Al-Qur'an dan Al-Sunnah. Kuala Lumpur: Al-Hidayah Publication.

Ayub, ME., Muhsin MK \& Ramlan Mardjoned (1996). Manajemen Masjid. Jakarta: Gema Insani Press.

Aziz, RA (2001). Pengantar Sosiologi Pembangunan. Kuala Lumpur: Dewan Bahasa dan Pustaka.

Badri, AK (2010). Hutang Piutang, Ar-Rahn, Hiwalah dan Kafalah. Accessed on6 July 2015 from http://uin-jkt.blogspot.com/2010/12/ googlef80e854ba6498f40html.html

Bennabi, M (2009). Asal Usul Masyarakat Manusia Rangkaian Hubungan Sosial (On The Origins of Human Society), transl. Muhammad Uthman El-Muhammady. Kuala Lumpur: Institut Terjemahan Negara Malaysia Berhad.

Chapra, MU (2001). “What is Islamic Economics", IDB Prize Winners' Lecture Series No, 9. Jeddah, Saudi Arabia: Islamic Research and Traning Institute, Islamic Development Bank.

Dusuki, AW (2013). "Kedinamikan Islam Terima Perubahan", in Sinar Harian, 14 August 2013.

Hanapi, MS (2013). “Tasawur Islam dan Pembangunan”. Kuala Lumpur: Penerbitan Dewan Bahasa dan Pustaka.

Hanapi, MS (2014). "Tasawur Ekonomi Islam", (ed.) Bagus Sigit Sunarko \& Zakaria Bahari, Kertas Kerja di Konferansi Internasional Pembangunan Islam 1 (KIPI 1), Universitas Jember, Jawa Timur, Republik Indonesia.

Hanapi, MS\& Mohd Tajul Sabki Abdul Latib (2003). Kamus Istilah UndangUndang Jenayah Syari'ah (Hudud, Qisas dan Takzir). Kuala Lumpur: Zebra Editions Sdn. Bhd.

Haron Din (1992). Tasawwur Islam. Shah Alam, Selangor: Pustaka Hizbi.

Haron Din (2015). Manusia dan Islam. Selangor: PTS Publishing Sdn. Bhd.

Hitti, Philip K. (2006). History of the Arabs (History of The Arab's: From The Earlist Time to the Present), transl. R. Cecep Lukman Yasin \& Dedi Slamet Riyadi. Jakarta: PT Serambi Ilmu Semesta.

Ibn Kathir, Abi al-Fida' al-Hafiz al-Dimasyqiy. (1989). Al-Bidayah wa alNihayah, Vol. 2. Beirut, Lubnan: Dar al-Kutub al-'Ilmiyyah.

Ibn Qudamah, Wawaffaq al-Din 'Abd. Allah Ibn Ahmad al-Maqdisiy. (1991). Mughni al-Muhtaj Ila Ma'rifah Ma'aniy al-Faz dan al-Minhaj, Vol. 7. Beirut, Lubnan: Dar al-Kutub al-Ilmiyyah. 
Isa, M. M. (2009). “Ekonomi Islam: Perspektif dan Cabaran”. Islamic Banking Encyclopedia. Accessed on 4 April 2014, from http: / /www.iefpedia.com/malay/?p=35

Ismail. J (2011). Amalan Bid'ah Keagamaan Zaman Jahiliah. Accessed on4 October 2012 from http: / / tafaqquhilmu.blogspot.com/2011/10/amalan-bidahkeagamaan-zaman-jahiliah.html

Jomo. K. S (1992). Islamic Economic Alternative: Critical Perspective \& New Direction. London: Macmillan

Khaf, M (1987). "Islamic Economics: Note on Definition \& Methodology". A paper is presented at International Workshop on the Methodology of Islamic Economics", Bayero University Kano, Nigeria.

Manan, M.A. (1984). "The Making of an Islamic Economic Society". Cairo, Egypt: International Association of Islamic Bank.

Mardiani, D (2012). Masyarakat Jahiliyah Pra-Islam Berhaji? Accessed on 2 October 2012 from http://www.jurnalhaji.com/masyarakat-jahiliyahpra-islam-berhaji-inilah-cara-mereka/

Musa, I (2009). Poligami Menurut Hukum Adat dan Emosi. Accessed on 9 October 2012 from http: / /jalanakhirat.wordpress.com/2010/03/08/poligami-menuruthukum-adat-dan-emosi/

Naim, A. S. M. \& Yousoff, R. (2003). Konsep Teori, Dimensi dan Isu Pembangunan. Shah Alam, Selangor: UITM Press.

Nasir, Z. M. (2010). Zihar: Amalan Masyarakat Jahiliah. Accessed on 14 October $2012 \quad$ From http: / zulhazmimohdnasir.blogspot.com/2010/03/zihar-amalanmasyarakat -jahiliah.html.

Nur Chamid M. M. (2010). Jejak Langkah Sejarah Pemikiran Ekonomi Islam. Yogyakarta: Pustaka Pelajar, Celeban Timur.

Nuralhadi (t.t.). Undang-undang Jenayah Islam Mengenai Jenayah Qisas Bunuh. Accessed on2 October 2012 from http://ustazabdulwahab.wordpress.com/jenayah/hukuman-qisas /

Prasetia, I. (2011). Dilarang Pakai Kaos Saat Beribadah. Accessed on9 October 2012 from http://www.bimapedia.com/2012/08/dilarang-pakai-kaossaat-beribadah.html

Sabran, R. \& Syam, R. (1985). Kaedah Pengajaran Bahasa Malaysia. Petaling Jaya, Selangor: Fajar Bakti.

Salleh, M. S. (2003a). "Tujuh Prinsip Pembangunan Berteraskan Islam”. Kuala Lumpur: Zebra Edition Sdn. Bhd.

Salleh, M. S. (2008). "Pengurusan Pembangunan Berteraskan Islam Konsep dan Perkaedahan" - Syarahan Umum Perlantikan Profesor pada 28 Julai 2001 di Dewan Kuliah A, Universiti Sains Malaysia. Penang: Universiti Sains Malaysia.

Salleh, M. S. (2011). "Islamic Economics Revisited: Re-contemplating Unresolved Structure and Assumptions", 8th International Conference on Islamic Economics and Finance, Center for Economics and Finance, Qatar Faculty of Islamic Studies, Qatar Foundation.

Salleh, M. S. (2011). "Pemikiran Ekonomi Islam Melayu", kertas kerja yang dibentangkan di Konferensi Internasional Islam di Alam Melayu, anjuran Program Pasca Sarjana UIN Sunan Gunung Djati Bandung (PPS UIN SGD) dengan kerjasama Akademi Siswazah Universiti Malaya, Malaysia (APIUM), di Gedung Merdeka Bandung, Indonesia, 20-22 November. 
Salleh, M. S. (2011). "Pemikiran Ekonomi Islam Melayu", working paper presented at the Konferensi Internasional Islam di Alam Melayu, organised by Program Pasca Sarjana UIN Sunan Gunung Djati Bandung (PPS UIN SGD) with the collaboration of Akademi Siswazah Universiti Malaya, Malaysia (APIUM), at Gedung Merdeka Bandung, Indonesia, 20-22 November.

Shuhawi, N. (1977). Rusum Jahiliyyah. Lahore: Urdu Bazar.

Siddiqi, M. N. (1989). Pemikiran Ekonomi Islam: Satu Tinjauan Penulisan Semasa (translation by. Mohd Amin Abdullah). Kuala Lumpur: Dewan Bahasa dan Pustaka.

Smith, W. R. (1990). Kinship \& Marriage in Early Arabia. London: Williams and Norgate Ltd.

Sobri, M. A. (2009). Mengenal Riba. Accessed on 11 October 2012 from http://mashoori.wordpress.com/tag/riba/

Suyantoro, FIS (2008). Muhammad Business Strategy and Ethics. Yogyakarta: C.V ANDI OFFSET.

Syakir, M. (1991). Al-Tarikh al-Islamiy Qabl al-Bi'thah, Vol. 1. Beirut: AlMaktab al-Islamiy.

Toshihiko, I. (1964). God and Man in the Koran: Semantics of the Koranic Weltanschauung. Tokyo: Keio Institute of Cultural Studies.

Wiroso, S.E. (2005). Penghimpunan Dana dan Distribusi Hasil Usaha Bank Syariah. Jakarta, Indonesia: PT Grasindo Press.

Yahya, M\& Ahmad Jelani Halimi. (1993). Sejarah Islam. Kuala Lumpur: Fajar Bakti Sdn. Bhd 